\title{
Conversations with Gerald Pratley (3)
}

\author{
By Allan King
}

Spring 2002 Issue of KINEMA

\section{FIVE FILMMAKERS IN CONVERSATION WITH GERALD PRATLEY (Part 3)}

The NFB's $60^{\text {th }}$ Anniversary has been celebrated leaving behind little of its contemporary production to raise the spirits and create enthusiasm among the Board's many long-time admirers and supporters. Founded in 1939 by the accomplished John Grierson, it has now, like its crown sister, The Canadian Broadcasting Corporation $(C B C)$, drifted far from where it was once anchored and away from what it was as a public service, lost on a sea of indifference and mediocrity. Kinema asked four filmmakers long associated with the $N F B$, documentary film, and $C B C$, to look back over what has been taking place during past years leading to today's disappointing and empty era. They are Gerald Graham, Grant McLean, Terence Macartney-Filgate, Donald Haig and Allan King. They talked to our associate editor and film historian, Gerald Pratley. In this issue, we publish the last of the five conversations, with Allan King who, as one of Canada's leading documentary filmmakers looks back over his career and takes an overall view of our world of documentary, features and television, past and present.

\section{(5) ALLAN KING}

My beginnings in filmmaking really came out of high school. One of my chums was Stanley Fox, who went on to film school at Simon Fraser. He was the head of the film department in Vancouver, and an editor there. Later on he taught at York University. Finally, he was program director at TV Ontario. Stanley and I went to school together. He was a very eager photographer, and worked in photography, and kind of graduated into wanting to make movies. He got hold of an inexpensive camera. We found we could get short ends of films from the labs. He had a printing machine and processor from Oscar Burritt, a film society pioneer who went to work in CBC-TV when it began.

The processor was half an oil drum with two barrel ends, and a rod through it, and you could wrap film around it and chromium wires across it. So you could actually wrap a hundred feet of film around this drum in the basement if you had all the lights out, and it was perfectly dark. You could put processing developer in it, and process your film. So Stanley processed the film in his basement and he had a wonderful printing machine, which is simply a synchroniser with a light on it and a rheostat, so the faster you wound, the brighter the light, and it automatically corrected its exposure. Stanley started making films, and I was sort of a stagehand and assistant. And other friends took part in them, and we had a little film unit, based out of Stan's house at Seventh and McDonald in Kitsilano, Vancouver.

And around the same time, the Vancouver film society resumed its showings after the war. In that first year, Stanley and I saw a great number of film classics, both silent and sound. And then we took over the projecting, and after that the running of the film society. We obtained the films we wanted to see and very quickly had an education in film, by the time we were 19 or 20 . So we had seen a lot of films, which is a wonderful education because really filmmaking, learning filmmaking in my experience, is about seeing as many great films as possible, an even the ordinary ones, and becoming really familiar with the literature. It is about making films, in your basement, on any basis whatsoever. It is like writing: if you need to have a pencil and pen and write and have some ideas, you will write. Additionally, to be in a community of people with whom you can fight, exchange ideas, espouse various aesthetic ideologies, argue about what does and really mean to make films, what are good films, what are bad films? That third stage occurred at CBUT (CBC Vancouver), at the beginning of television. Stanley got a job there.

I was touring and hitchhiking around Europe and I got a letter from him, and he said they've opened up television. Any damn fool can get a job here because nobody knows what they are doing. From top to bottom we're all amateurs, and you could probably get a job too. So I came back and I got a job and became a production assistant. It was like a film school in the sense that we were all learning as we went. Some of us had some kind of background. Stan and I as I said had both been involved in filmmaking. Stanley primarily, he watched, and a few of our other friends, Ron Kelly, Darryl Duke and others, we used to criticise each others' work with enormous vehemence and passion, and if that is the way you defined yourself you 
find your voice as a filmmaker. And that is exactly how it worked for me. I found I was different from other people, and each of us was different. We found we were in fact becoming known within a very short time, and we were astonished because we thought we were totally different from each other. But from the long distance of Montreal we looked like a group; we were all on the West Coast ridge, so we were called the "West Coast film school."

The first film that we did was called Blub, and it was a satire on Maya Deren. It was a surrealist film at the time -- and it was very funny. And, in fact, it won honourable mention at the Canadian Film Awards. I continued working in Vancouver, made four films there, the first was Skid Row, which was greatly admired by John Grierson, he was very fond of it. That brought me some attention, and after four films, for a couple of reasons, I left Vancouver. The CBC became very bureaucratised and as early as that the seeds of its own self-destruction, or its own impotence, were being sown and established. I found, for example, I couldn't engage or work with the cameraman I wanted to work with. The cameraman was assigned to me like a test taker, and you didn't have any choice, and I found that didn't work very well. They took over a large building and hired forty cost accountants. Arguably, it never recovered in Vancouver. Well, that's not entirely true, they did have some good times after that with some people. But, at any rate in 1958 after two or three years as a filmmaker there, a television program maker, I began life as an independent director and producer.

When I set off I thought to myself "Allan you are absolutely crazy." There were no independent producers or directors anywhere in Canada that I knew of except "Budge" Crawley in Ottawa. He was basically doing "industrials." There were a couple others who were doing industrial film or films for government, which were public relations kinds of things. They didn't make movies. So, I didn't know if I would ever get work or not. Fortunately, on my way to Europe I stopped in Toronto to see who I could make films for, and the CBC's Ross McLean was kind enough to say "Anything you want to do, write and tell me, and I will be happy to look at it." At this time, Grant McLean was with the film board. Ross MacLean had been in radio in Vancouver, and in the very beginning of television in Toronto. He did the series called Tabloid, an evening interview show. Then he did a series called Close Up which was enormously popular, and had its slot on Sunday nights, and you were guaranteed a huge national captive audience, which was wonderful for any filmmaker. The other Ross McLean who had been with Vincent Massey in London, he became the commissioner of the NFB after Grierson left, at the time when the Government wanted to get rid of the Film Board.

So, I arrive on my European travels on the island of Ibiza. Then I did a film, which was not successful and I don't think saw the light of day, and was written by Clifford Irving, the great forger. And then the next film was a one-hour special on Morocco, which we shot in Ouarzazate which is a Berber town on the far side of the Atlas mountains. A third of it was in Marrakech, and a third of it was in Fez. We made it, a one-hour, for nine thousand dollars. I sent them back to Ross, who used and paid for them, which helped to pay my way. My wife and some friends were with me, we lived, in a way, quite casually, wherever you could get a bed. It was very inexpensive travelling in those days, and we had $\$ 3$ per diem per family and survived on it. The hotels usually cost a dollar. We had one in Marrakech; it was called The Mickey Mouse. We went in to inspect it and saw a mouse indeed running down the bathtub, in the room, but no, we had a marvellous time.

We edited our films in Ibiza, in the house that we had there, which was like an apartment in a cave. At least, it backed into the main hill -- Ibiza had a sort of hill, a castle up on top or a church up on top. We edited it there. Then continued on, George Robertson and I made a film on refugees, called Where will they go? Then I found we had to move to London, because it really wasn't practical getting film in and out of Franco Spain. So I went to London and set up a studio there with a number of people. Richard Leiterman -he'd come out of Vancouver -- joined me as a camera-assistant and then became the cameraman. Bill Wade joined as an editor. We were sort of the hottest item in town because we began shooting cinema vérité, for the British. We were the first to have $16 \mathrm{~mm}$ on a substantial basis, so everybody wanted to use us.

Then I met Derek Hill. He was our first agent and sales representative. He had his own outfit, but he represented filmmakers. And I remember going to Richard William's studio, and he was set up there. I was really impressed with all the certificates he had on the wall form so many film festivals. So I went back to 
Derek and said, "How did he get those?" and he said "It's easy, send your films to festivals and in a year you've got a wall full." And that's what we did. Derek would send our films to festivals. Well I returned home and I made at that time, my first drama in New York, called Bjorn's Inferno, with a cameraman and sound man, writer, production-manager, and two or three amateur actors. That was for a series called Document, which was a once a month, one-hour documentary inserted into the seven days of This Hour has Seven Days series.

I had become established in London with my own company. There were many Canadians there. Sidney Newman was the head of BBC drama. He started at Granada and then moved to BBC. He was a very powerful force there. Ted Kotcheff was there, Mordecai Richler, Norman Jewison, Sidney Furie and Elaine Grant and Bernard Braden and his wife Barbara Kelly, who did interviews for Ross. These were for Close-up. We made great efforts doing interviews, at first and we shot all sorts of famous people, like John Paul Getty and Bertrand Russell. In fact we did an extraordinary interview with Orson Welles with Bernie doing the interviewing in the film. We shot an hour-and-a-half, and the CBC used one hour and 23 minutes. It was only supposed to be a half-hour interview, but they got their money's worth.

I left in '67. People started coming back or going to Los Angeles. Countries always go through a phase where the people flock to the place that becomes hot, a terrific exchange of ideas, around some particular thing -in that case television, the start of television, so a lot of Canadians who had experience went to Britain in part because the $\mathrm{CBC}$ tightened up. The $\mathrm{CBC}$ went into a government turned liberal to conservative, they brought a guy called Capt. Briggs from Nova Scotia, who was some sort of a martinet, and the budgets dropped. So we lost our first generation of TV people. Then the CBC went into a sort of stagnation for four or five years. But they were still doing a lot of public affairs. The drama department seized up from being what was really a world class television production centre in the 50s. Then it went into a decline and became a second class, relatively mediocre place for quite a while.

I attribute this to the government and the wrong people getting in to run it. It seems to be a very common syndrome with large organizations. They start with a new mandate, with a fresh mandate, and they have lots of bright and talented people. There's usually money around and opportunity and fresh visions collect around it. The best of those people, for one reason or another, tend to go away, to either advance their career if the place is a relatively a second city like Toronto. And their jobs are taken over by administrators and secretaries. As they move up and out, less talented, less imaginative, less creative people take over their jobs as producers, and they start to hire people who reflect the mediocrity that they've brought to the job. And I have seen that in many organisations over the years. It happens at the NFB and major corporations, like Imperial Oil. It's the nature of humankind, I think. The best and brightest tend to move on to something fresh, and the dull and mediocre stay till the very end and watch it go sour.

And when I returned to Canada, I came back with an exuberance because there were a lot of things happening like Expo and we had been doing things from England for Canada, and one of the reasons I came back was that most of things I was doing were for a Canadian market, so I might as well be living in Canada. And for a number of reasons I wanted to leave England. I always said it was because I felt a great patriotism rising out of Centennial year, but it really was for personal reasons. It was a marriage conflict indeed, and the next film I made was a film about a marriage conflict. A fine woman that I then divorced at that time and was separated from, but I needed to leave to separate. And I wanted to work with people here. But the difficulty was that there was the CBC, which did all in-house production here at that time. There was CTV, which was also a totally in-house production. And the NFB which seemed out of bounds for my work. So the life of an independent producer, or independent filmmaker in Canada was bound in despair indeed. It was a very very hard slot here, and it took really ten or fifteen years before that transformed. That was the climate here at that time. It was very severe.

I haven't made very many of the films that I really like to make. I found it was never possible to financially organize them. Warrendale, Skid Row, A Married Couple, Come on Children were the first. But by the time I got to the last one I couldn't raise a family on documentary filmmaking. So meanwhile I did things like episodic television for Hitchcock. Just did two episodes in a series called Flesh and Blood. I did a lot of Road to Avonlea, I think probably more than almost anybody else.

I sometimes watch my own. In truth, now that they have video assist on cameras, I don't even have to watch 
rushes anymore because I can see it as it is being shot. I know what I've done and I know what I want to do, and they work very well. But I don't stay to do the editing because everybody else interferes, and that gets confusing. The producer has his vision, and so on and so forth. And if I am not in charge of it and not going to control it then it is a waste of my time. They end up doing it the way they want to do it in any event, so it is kind of silly to go through the pretence of editing and then letting somebody else finish it. They should be responsible for it. It's just like being a doctor, you see. You're hired to do a professional thing. You're not involved in the script. You're not involved in the script development. They're interested to hear if you have criticisms and problems but interference from the network is enormous. So I just come in to direct the cameras and the cast. I do my job, and they like it. You describe your description, and if they want to take it, terrific, if they don't they can die or they can fly, whatever. This of course is a very different method from the way I made A Married Couple and Warrendale.

That is to say, we spent, in that case, ten weeks, and in Warrendale I think it was five or seven weeks. And it was specifically being in the environment all of the time, fifteen, sixteen hours a day, shooting from every conceivable angles and points of view. It was a process, where I would shoot so much material, and then spend a long time editing and selecting it. I loved it. Because you get very fresh and original stuff that way. In cinéma vérité, what people essentially do is to imitate life. And they do it by trying to capture characters and write a text for them to read. And they actually try to write a subtext at the same time, when actual people give you a subtext all the time as they are talking. You have people talking away in a scene in real life, and there is a whole subtext, of unconscious stuff that is going on at the same time. And it is the same as drama. Drama is truly an imitation in this sense. Ordinary transactions between people, whether it is a conflict or not what you end up with is, finally, in ordinary life, is that people do in fact play scenes. And as I said, they go about an hour, fifty minutes. Sometimes you walk in on something happening and you're in the middle of the scene, and you don't have the beginning so it won't work. Sometimes people will break it off because they don't really want to pursue it and it's aborted. But ordinarily, if there's something of an issue, it'll go for about an hour, and it'll be about five minutes of stuff when you edit it. And movies are very much the same way.

Conferences are the same: if you get people together to do some work, if it's a four day conference people will at the first day talk about what they want to do, they'll review what the tasks and the agenda, what they came there for. The second and most of the third day they waste time to avoid the work, because nobody likes to work. Part way through the third day they will start to lock onto it, you'll have a fight, a climax, people really argue and get into specific turmoil. Then they'll feel we have to go home tomorrow, so they'll usually leave it on the end of the third day, say goodbye and come back on the fourth morning and then they have to make peace because they have to go home and have a life. And then they resolve it. And then they sort of review what they've done and congratulate themselves, and everybody goes home.

And it's just the way a movie does: a movie starts, or a sonata -- but not exactly the same. And it comes from real life. The excitement of direct cinema, or that kind of work is for me, that things are happening. If people really want to explore something, they will do it, and you end up with a drama. If they, in turn, decide not to, then you might not have a drama. So it's very risky. But the drama that you get is very fresh indeed because it is totally impulsive. The stuff that people produce has that kind of reality and I find it ... I learned a great deal. I learned an enormous amount from the film I just finished doing because of that example. I call them "actuality dramas."

It has been said that once people know they are being photographed they know they are and they tend to change their behaviour, perhaps accordingly. Maybe they don't want to be as frank or as natural as you want them to be because they say only children and animals are completely unaware of cameras or what they can do but I don't agree with that. Animals maybe, and I don't think even animals, unless you are using a telephoto lens. I think working with people with a telephoto lens or hidden camera is very unproductive. The kind of feeling that occurs with it tends to be uncomfortable for those watching, it makes them a voyeur, because you can feel people. It's not a relationship really with the audience, so what you get is a kind of zoo behaviour. It's like a one-way mirror, hidden mirror; it doesn't yield very much, in my experience.

What does happen, and it happened certainly with the case of the children of Warrendale and certainly the case with any kind of filming I've done of that sort, people in fact do use the camera and engage in that kind 
of filming because they want to express something. The children in Warrendale would not have done it or said yes had they not quite directly wanted to express something. We had long talks, and the whole premise of the film was that the children deeply resented the fact that they were unacceptable to society. And their question was "What is so wrong with us that people can't look at us or we can't be photographed and put in the paper? We are non-beings in this society." That was a time when, and it's still the case, when people don't want to deal with it. So, the children were different with the camera. They used the camera in the same way that I am being used with this conversation. You want something from me. You would like me to talk about various things. And I will be more or less candid depending on all sorts of considerations. But this isn't the me that is ordinarily walking around this house. I am talking to you now because people will listen to this in the future, or say this is an oral history.

Some of the things I have said are less candid than they may or might not be if it were another context or another meaning, I would speak in a different way. We are many different people, depending on who we are talking to, what we want to express and what's the truthfulness of the expression, what's the past. Ordinarily, in the documentary you have a task. For me it's always I want to explore a territory, a universe of discourse as Aristotle used to call it. So, once you've set that universe of discourse that you want to explore, then you want to look for people who are involved in it, and you say to them I think this is a particularly interesting thing you have going on here, and I would like to film it with you, and I would like to explore it with you. They will either feel yes, it is worthwhile and they would like to do that, and take part of the enterprise, or they'll tell you to buzz off. So then they are aware.

Billy and Antoinette certainly were a little different for the camera than not. But you see it's not really different in the sense that people can't invent themselves out of whole cloth. What they produce for the camera is as much them as what they produce, or what they are like when the camera isn't there. It's still their stuff, and even though they may wish to pose in some way or give some sort of impressions we know, and even they know, what's going on. And furthermore, their unconscious expression, their body language, the subtext as it were, is perfectly there for anybody to see and pick up. So, in a sense there is no real hiding.

But I think there is a difference in quality with A Married Couple and Warrendale in the sense that there's a range with Warrendale and also a depth of emotionality, the expression or sense of outrage that these children, or some of them express and felt about what had happened to them in life. The outrage at not having had the parenting that a child needs and requires and is desperate for. These children have been profoundly deprived; they've been robbed of parents. That is very painful. A child will ordinarily scream, and they do. And that moves everybody. In marriage conflicts, with Billy and Antoinette for example, the primary thing it seems to me was a fear of intimacy, which we all also experience and know. We get together with great intensity of feeling but after awhile we have to separate because otherwise we merge and lose our identity. So we have to have our separate identity, at the same time we crave merging. It is the nature of life. But we often use a lot of devices, and Billie and Antoinette did, so it becomes a black comedy. It's very painful, but it's a comedy. But it also becomes just a touch repetitive or one can see the pattern, and finally one says "how painful, how true, how...." One way or another we are all like this. It's a difficult level of expression, so I like to film a lot, but I don't think it's as powerful or it reaches the depth that Warrendale does. And I say that not as a matter of pride because these things are gifts. The film comes to you, you have to be receptive enough, and your crew has to be receptive enough to hear and to shape and all of that. But it's not as if you've invented it.

At the opening of A Married Couple you were asked that if for example, you had heard about Billy and Antoinette, and Warrendale and you decided to script it in dramatic form, and film them with perhaps actors or with Billy and Antoinette, or with the children -- do you think it would have been a method you would rather have done or not done? Do you think it might have been better or not better? You can in a sense. What, for example, A Married Couple yields is similar to, but quite different from than, say Scenes From a Marriage, which I suspect Bergman had seen in Sweden because we shared distribution at that time. Or who didn't see it but a film or play like Who's Afraid of Virginia Woolf? is a similar kind of territory. So you can write it if you have great skill as Edward Albee has. And you can invent if you have great skill as Bergman has. It's still a different genre, you get different stuff from it. You can get at it either way. I find it's interesting to do it with actual people. I have a sense one gets an insider kind of perspective. It brings 
together the kinds that I have observed actually being with people. So, it's another way of expressing the experiences I've had.

I tell you, I used to come back to Canada from England every year to get some commissions for work to keep the shop going and all the rest of it. Every time I stopped at the Film Board and went to see people and ask, "How are things now George? Jane? Or whoever it was?" "Oh Allan, never been worse, never been worse." Then I'd come into Toronto to the CBC: "Well Bill, John, Mary, how are things going?" "Oh Allan, never been worse!" It's never been worse for forty years in both places and after a while you think this is a neurosis, this is a reflection of people floating up through the bureaucratic bit and going off somewhere else. I tried to remain a true independent if I couldn't get any assignments from them, I went ahead and did something that I was interested in. But one way or another I haven't been permanently employed by anybody since 1958. But I kept going with bits and pieces.

When I found I couldn't make a living doing documentaries I went bankrupt, as a matter of fact. I started doing drama for the CBC for David Peddie, for a series called To See Ourselves, half-hour dramas of short stories like Baptising of Alice Munro, or A Bird in a House by Margaret Lawrence, and learned to film drama in that way. And it was a very useful and interesting education. Then I raised money for W. O. Mitchell's Who Has Seen the Wind? and directed that, then did Silence of the North, a feature for Universal. I was very happy with it and there were many things that I liked about it, but I didn't have control of it all for a start. The star wanted to direct it, the producer wanted to direct, and unfortunately I didn't say "Well please go ahead, give me my fee and I'll go away." I had always been used to being able to diplomatically finesse my way through anything and get what I wanted, but this time I did not. After that I went back and did a documentary called Whose in Charge? which created an enormous storm, got me called "the media monster of the 1980's." But it was similar in some ways to A Married Couple and Warrendale in that it was a free form, spontaneous event. Then I went back and from there started doing a lot of movies.

Overall I think the cultural scene here has transformed for the best, for the better. It would be inconceivable that we would be able to produce 80 features, seventy or eighty features in a year in this country twenty years ago, thirty years ago, we could have produced one or two. So we have a lot of film going on. Television, I find, has transformed astonishingly. We have an enormous amount of independent production. We have a huge amount of Canadian production on television every night, where we didn't have before. It is still much less than we need in order to preserve ourselves as an independent culture, in order to have a different voice than the American voice, to preserve in the harrow and diverse contribution. But it is hugely better than it was when I came back to Canada in the 1960's. Transformed. That has been the work of very hard lobbying, arguing and building a complete structural transformation of television. Enlightened public policy. Hard work to do; you can only do it bit by bit because you can't invent the world in a day. You can if you're God and do it in six. But for the rest of us it takes a long time. All of that's happened: we have things to do.

It is a problem that we spend a lot of money training people, and then don't provide the resources with reinstated work. So in fact, we're a wonderful training school for Los Angeles. That's a serious disability, which has to be addressed. But at least we are training them, and at least they are getting a chance to make first films, so we are developing a lot of talented people. The number of people who can shoot, design, direct, write and so on in films is enormous. We have a huge business going here now. Everybody complains because most of it is American. But it also affords an income for those people who want to then do their own films. That is very helpful. What we have to do is simply continue to improve the creativity and improve the conditions under which creativity can flourish. It is very hard to get everybody mobilized to do it. Because everybody likes to go their own different way, everybody likes to stand on the post and crow like cocks, fight and yell and so on. But in fact the feature film policy that I think is going to be emerging out of this present round is likely to be a big improvement over what we've had.

Let's put it this way, the audience for original Canadian serials, episodic television, which has a distinctive Canadian flavour, is bigger than things like Kung-Fu and a lot of that kind of stuff that we are also doing. Head to head, in the schedule, Canadian stuff does better in Canada. But it doesn't necessarily do better in the States. So you have to be able, if you're going to have a functioning enterprise, you do have to make a profit. You have to have a return on capital. So you have to do both of those things. The CBC ruins much of its good work, particularly its films, with incessant commercials. As for the NFB, there is no place for us 
there now. It's become a private workshop lacking logical sequence and disconnected from reality. (Transcribed by Carrie Cardoso)

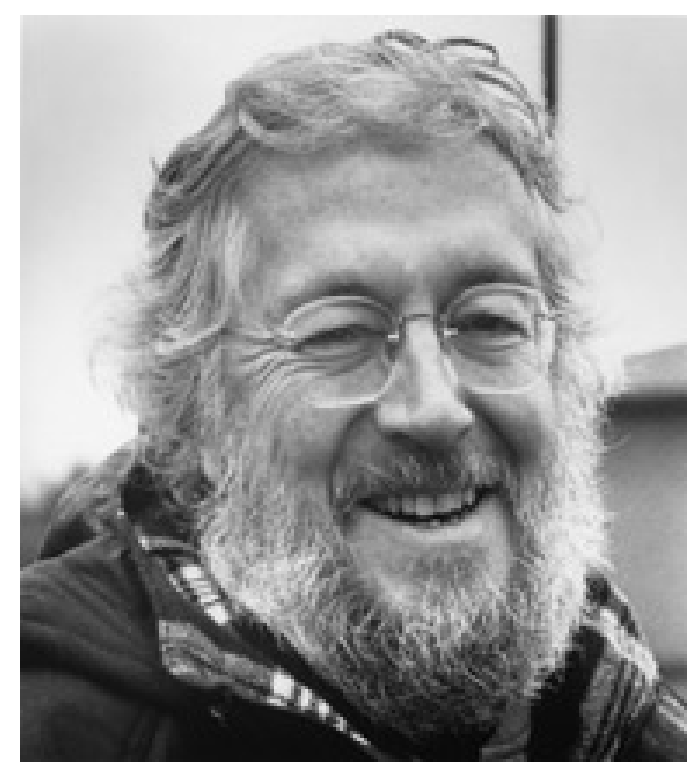

Figure 1: Director Allan King

\section{References}

Allan King filmography

The Dragon's Egg: Making Peace on the Wreckage of the 20 ${ }^{\text {th }}$ Century (1999)

Twice In a Lifetime (1999)

Leonardo: A Dream of Flight (1998)

By Way of the Stars (1992)

Kung Fu: The Legend Continues (1992)

All the King's Men (1991)

Neon Rider (1990)

Road to Avonlea (1990)

Blackmailers Don't Shoot (1989)

Termini Station (1989)

Friday the 13th (1987)

Last Season, The (1986)

Alfred Hitchcock Presents (1985)

Twilight Zone, The (1985)

Dream Me a Life (1985)

Who's In Charge (1983)

Ready for Slaughter (1983)

Silence of the North (1981)

One Night Stand (1978)

Who Has Seen the Wind (1977, (as Allan Winton King)

Maria (1977)

Red Emma (1976)

Baptizing (1975)

Come On Children (1973)

Bird in the House (1973) 
Married Couple, A (1969)

Warrendale (1967)

Running Away Backwards (1964)

Rickshaw (1960)

Pemberton Valley, The (1957)

Skid Row (1956) 